\title{
PEMANFAATAN JERAMI PADI FERMENTASI DENGAN MOD-71 TERHADAP PERFORMANS DOMBA SEI PUTIH JANTAN
}

\author{
(Utilization of Fermented Rice Straw by Mod-71 on Performaces of \\ Sei Putih Lamb)
}

\author{
Mhd. Firman Ketaren ${ }^{1}$, Tri Hesti Wahyuni ${ }^{2}$ dan Zulfikar Siregar ${ }^{2}$ \\ 1. Mahasiswa Program Studi Peternakan Fakultas Pertanian Universitas Sumatera Utara \\ 2. Staf Pengajar Program Studi Peternakan Fakultas Pertanian Universitas Sumatera Utara
}

\begin{abstract}
Rice straw fermented with MOD-71 could be increasing the protein content of feed on the implications of increased consumption of dry matter. This study aims to determine the use of rice straw fermented with various levels of MOD-71 on feed intake, body weight gain and feed conversion of Sei Putih ram lamb. Research was conducted at the Faculty of Agriculture, University of North Sumatra from May 2012 to August 2012. The design used in this study was a randomized block design (RBD) with 4 treatments and 3 groups. Which in use 12 ram lamb with initial body weight gain 10,675 $\pm 0,30 \mathrm{~kg}, 12,762 \pm 0,22 \mathrm{~kg}$, and $\pm 14,637 \pm$ $0,24 \mathrm{~kg}$. The treatment consists of P0 (unfermented rice straw), P1 (straw fermented with $2 c c \mathrm{MOD}-\overline{\mathrm{O}}$ ); $\overline{P 2}$ (straw fermented with 4cc MOD-71), and P3 (straw fermented with 6cc MOD-71). The results showed that administration of fermented straw MOD-71 were not significantly different $(P>0.05)$ on feed intake, body weight gain and feed conversion of Sei Putih ram lamb. The results showed the average feed intake 497,40 (g /head / day). Average daily gain 21,13 (g /head / day). Average feed conversion 23,58.
\end{abstract}

Keywords: Rice Straw, Fermentation, MOD-71, Sei Putih Ram Lamb.

\begin{abstract}
ABSTRAK
Jerami padi yang difermentasi dengan MOD-71 berperan dalam peningkatan kandungan protein pakan yang berimplikasi pada peningkatan konsumsi bahan kering. Penelitian ini bertujuan untuk mengetahui penggunaan jerami padi yang difermentasi dengan berbagai level MOD-71 terhadap konsumsi pakan, pertambahan bobot badan, dan konversi pakan Domba Sei Putih. Penelitian dilaksanakan di Fakultas Pertanian Universitas Sumatera Utara pada bulan Mei 2012 - Agustus 2012. Rancangan yang digunakan dalam penelitian ini adalah rancangan acak kelompok (RAK) dengan 4 perlakuan dan 3 kelompok. Penelitian ini menggunakan 12 ekor domba dengan bobot awal rata-rata $10,675 \pm 0,30 \mathrm{~kg}, 12,762 \pm 0,22 \mathrm{~kg}$, dan $\pm 14,637 \pm 0,24 \mathrm{~kg}$. Perlakuan terdiri atas $\mathrm{P}_{0}$ (jerami padi tanpa fermentasi); $\mathrm{P}_{1}$ (jerami fermentasi dengan $2 \mathrm{cc} \overline{\mathrm{M} O D}-71$ ); $\mathrm{P}_{2}$ (jerami fermentasi dengan 4cc MOD-71); dan $\mathrm{P}_{3}$ (jerami fermentasi dengan 6cc MOD-71). Hasil penelitian menunjukkan bahwa pemberian jerami fermentasi MOD-71 tidak berbeda nyata $(\mathrm{P}>0.05)$ terhadap konsumsi pakan, pertambahan bobot badan dan konversi pakan Domba Sei Putih. Hasil penelitian menunjukkan rataan konsumsi pakan 497,40 (g/ekor/hari). Rataan pertambahan bobot badan 21,13 (g/ekor/hari). Rataan konversi pakan 23,58 .
\end{abstract}

Kata Kunci: Jerami Padi, Fermentasi, MOD-71, Domba Sei Putih.

\section{PENDAHULUAN}

Ketersediaan bahan pakan di Indonesia khususnya di Sumatera Utara terutama ternak ruminansia yang berupa hijauan sangat fluktuatif tergantung pada musim. Pada musim hujan hijauan pakan ternak sebagai pakan utama ternak ruminansia melimpah, sedangkan pada 
musim kemarau sangat terbatas sampai tidak ada produksi sama sekali tergantung lamanya musim kemarau.

Perubahan fungsi lahan dan iklim membatasi ketersediaan hijauan pakan yang merupakan makanan pokok ternak ruminansia. Optimasi pemanfaatan limbah pertanian dan agroindustri dapat memperbaiki ketersediaan pakan. Integrasi dengan usaha pertanian merupakan alternatif untuk pengembangan peternakan yang berkesinambungan. Dalam usaha mencukupi kebutuhan pakan ternak, maka jerami padi dapat digunakan sebagai bahan pakan alternatif untuk ternak ruminansia khususnya ternak domba di Sumatera Utara dan Indonesia pada umumnya.

Kadar lignin yang tinggi pada jerami padi dan rendahnya kandungan nutrisi sehingga dibutuhkan teknologi pengolahan terhadap jerami padi untuk menurunkan kadar lignin dan meningkatkan daya cerna jerami padi dapat dilakukan dengan melakukan fermentasi menggunakan MOD-71.

Berdasarkan uraian di atas maka penulis tertarik untuk menelaah sejauh mana peluang pemanfaatan jerami padi dipergunakan sebagai pakan untuk ternak ruminansia. Penulis akan mengolah jerami padi tersebut dengan cara fermentasi menggunakan MOD-71 menjadi pakan yang lebih baik dan mampu meningkatkan performans domba Sei Putih jantan.

\section{BAHAN DAN METODE PENELITIAN}

\section{Lokasi dan Waktu Penelitian}

Penelitian dilaksanakan di Laboratorium Biologi Ternak, Program Studi Peternakan, Fakultas Pertanian, Universitas Sumatera Utara, Medan. Penelitian ini berlangsung selama 3 bulan dimulai dari bulan Mei 2012 sampai dengan bulan Agustus 2012.

\section{Bahan dan Alat Penelitian}

Bahan yang digunakan antara lain: Domba lokal jantan sebanyak 12 ekor dengan rataan bobot badan awal 10,675 $\pm 0,30 \mathrm{~kg}, 12,762 \pm 0,22 \mathrm{~kg}$, dan $\pm 14,637 \pm 0,24 \mathrm{~kg}$, pakan konsentrat yang terdiri dari bungkil inti sawit, dedak padi, onggok, pod kakao, molasses, urea, mineral mix dan garam. Jerami padi fermentasi sebagai pengganti pakan rumput ternak, MOD-71 untuk fermentasi jerami padi, obat-obatan seperti obat cacing (kalbazen), anti bloat untuk obat gembung, Rhodallon untuk desinfektan dan vitamin, air minum diberikan secara ad libitium. 
Alat yang digunakan antara lain: Kandang individual 12 unit dengan ukuran 1 x 0,5 $\mathrm{m}$ beserta perlengkapannya, tempat pakan dan minum, timbangan untuk menimbang bobot hidup berkapasitas $50 \mathrm{~kg}$ dengan kepekatan $2 \mathrm{~kg}$, timbangan berkapasitas $2 \mathrm{~kg}$ dengan kepekatan $10 \mathrm{~g}$ untuk menimbang pakan, chooper digunakan untuk mencooper bahan pakan, grinder digunakan untuk menghaluskan bahan pakan, thermometer digunakan untuk mengetahui suhu di dalam dan diluar kandang, alat pembersih kandang, alat penerangan kandang, dan alat tulis untuk menulis data. Kandungan nutrisi bahan pakan tersaji pada Tabel 1.

Tabel 1. Formulasi Ransum Konsentrat Selama Penelitian

\begin{tabular}{lrrrrr}
\hline \multicolumn{1}{c}{ Bahan } & Jumlah Bahan & PK & \multicolumn{1}{c}{ SK } & \multicolumn{1}{c}{ LK } & \multicolumn{1}{c}{ TDN } \\
\hline Kulit Coklat & 17.5 & 1.442 & 6.5135 & 0.2485 & 8.6065 \\
Onggok & 13.5 & 0.162 & 1.87785 & 0.027 & 10.0035 \\
Bungkil Inti Sawit & 37 & 5.698 & 6.4565 & 0.888 & 29.97 \\
Dedak Padi & 23 & 3.174 & 3.4431 & 1.886 & 14.789 \\
Molasses & 5 & 0.2 & 0.019 & 0.004 & 4.05 \\
Garam & 1 & 0 & 0 & 0 & 0 \\
Mineral & 1 & 0 & 0 & 0 & 0 \\
Urea & 2 & 5.6 & 0 & 0 & 0 \\
\hline Total & 100 & 16.276 & 18.30995 & 3.0535 & 67.419 \\
\hline
\end{tabular}

\section{Metode Penelitian}

Adapun rancangan penelitian yang digunakan adalah rancangan acak kelompok (RAK) dengan 4 perlakuan dan 3 kelompok. Perlakuan yang akan diteliti sebagai berikut :

Ransum perlakuan yang diberikan adalah sebagai berikut :

P0: Jerami padi tanpa fermentasi + konsentrat

P1: 2 cc MOD-71 /1 Kg jerami padi + konsentrat

P2: 4 cc MOD-71/1 Kg jerami padi + konsentrat

P3: 6 cc MOD-71/1 Kg jerami padi + konsentrat

Model linier yang digunakan untuk rancangan acak kelompok (RAK) adalah :

$$
\mathbf{Y}_{\mathbf{i j}}=\boldsymbol{\mu}+\mathbf{T}_{\mathbf{i}}+\mathbf{B}_{\mathbf{j}}+\sum_{\mathbf{i j}}
$$

Keterangan : $\mathrm{Y}_{\mathrm{ij}}=$ Nilai pengamatan dari perlakuan ke-i dan ulangan ke-j

$\mu \quad=$ Nilai tengah umum

$\mathrm{T}_{\mathrm{i}} \quad=$ Pengaruh perlakuan ke- $\mathrm{i}$

$\mathrm{B}_{\mathrm{j}} \quad=$ Pengaruh blok ke- $\mathrm{j}$

$\sum_{\mathrm{ij}}=$ Pengaruh galat dari perlakuan ke-i dan ulangan ke-j 


\section{Peubah Penelitian}

\section{Konsumsi Pakan}

Konsumsi pakan diperoleh dengan menghitung selisih jumlah pakan yang diberikan dengan sisa pakan setiap harinya dan dinyatakan dengan gram per ekor per hari (Parakkasi, 1999).

Konsumsi Pakan $=$ Pakan yang diberikan $($ dalam \% BK $)-$ Pakan yang sisa $($ dalam \% BK).

\section{Pertambahan Bobot Badan Harian (PBBH)}

Pertambahan bobot badan dihitung dengan cara membagi selisih bobot badan (bobot akhir - bobot awal) dengan lama hari penimbangan. Dilakukan selama satu minggu sekali, dinyatakan dengan gram per ekor per hari (Tillman et al., 1998).

$$
\mathrm{PBBH}=\frac{\text { bobot akhir }- \text { bobot awal (g/ekor) }}{\text { lama pemeliharaan (hari) }}
$$

\section{Konversi pakan}

Konversi pakan dihitung dengan cara membagi angka rata - rata konsumsi bahan kering per ekor per hari dengan angka rata - rata produksi pertambahan bobot badan per ekor per hari (Anggorodi, 1995).

\section{Konversi Pakan $=$ pakan yang dikonsumsi $(\mathrm{g} / \mathrm{hari})$ \\ PBBH (g/hari)}

\section{Skema pengaktifan bioaktivator MOD-71}

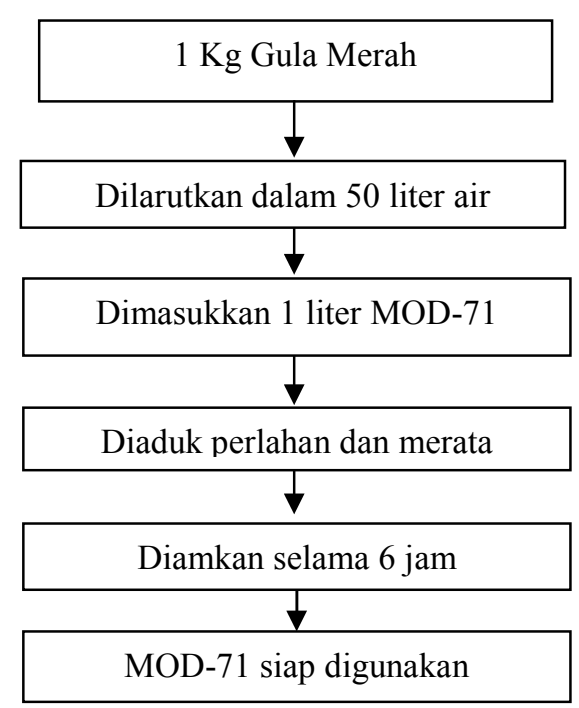




\section{Skema Proses fermentasi jerami padi dengan MOD-71}

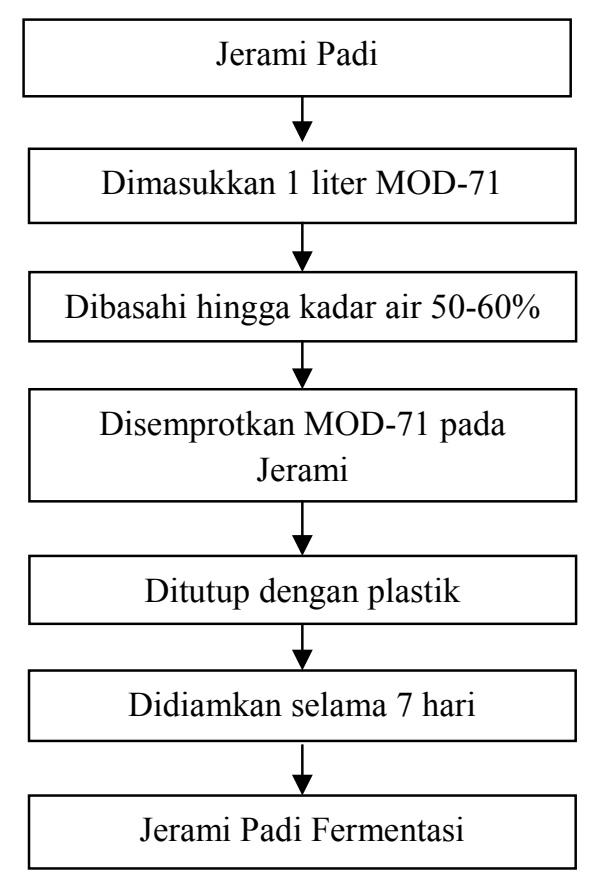

HASIL DAN PEMBAHASAN

\section{Rekapitulasi Hasil Penelitian}

Rekapitulasi hasil penelitian dari penggunaan jerami difermentasi dengan MOD-71 terhadap performans domba dapat dilihat pada Tabel 2.

Tabel 2. Rekapitulasi hasil penelitian

\begin{tabular}{lccc}
\hline \multirow{2}{*}{ Perlakuan } & \multicolumn{3}{c}{ Parameter } \\
\cline { 2 - 4 } & $\begin{array}{c}\text { Konsumsi Pakan } \\
\text { (g/ekor/hari) }^{\text {tn }}\end{array}$ & $\begin{array}{c}\text { PBB } \\
\text { (g/ekor/hari) }^{\text {th }}\end{array}$ & Konversi Pakan $^{\text {tn }}$ \\
\hline $\mathrm{P}_{0}$ & 465.76 & 20.37 & 22.88 \\
$\mathrm{P}_{1}$ & 488.78 & 20.94 & 23.33 \\
$\mathrm{P}_{2}$ & 491.37 & 22.39 & 21.96 \\
$\mathrm{P}_{3}$ & 543.70 & 20.82 & 26.15 \\
\hline
\end{tabular}

Keterangan : tn $=$ tidak berbeda nyata 


\section{Konsumsi Pakan (BK)}

Konsumsi pakan adalah kemampuan ternak dalam menghabiskan sejumlah pakan yang diberikan. Konsumsi pakan dapat dihitung dengan pengurangan jumlah pakan yang diberikan dengan sisa pakan yang ada.

Perbedaan konsumsi pakan dari keempat perlakuan diilustrasikan pada Gambar 1. Berdasarkan gambar 1 dapat dilihat rataan konsumsi pakan domba sebesar $497.40 \mathrm{~g} / \mathrm{ekor} / \mathrm{hari}$ dengan konsumsi tertinggi pada P3 sebesar 543.70 g/ekor/hari dan konsumsi terendah pada P0 sebesar $465.76 \mathrm{~g} / \mathrm{ekor} / \mathrm{hari}$.

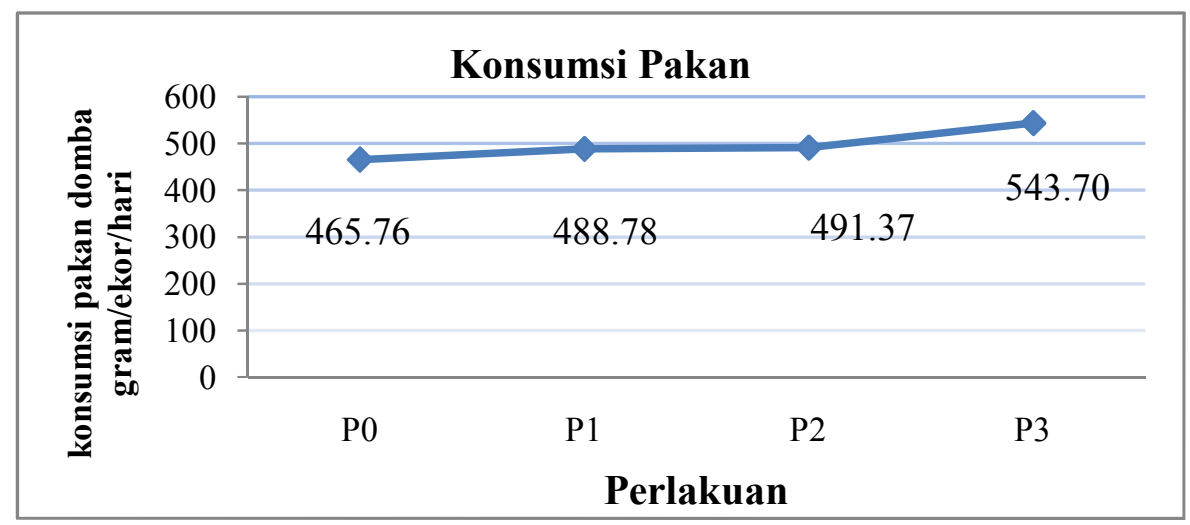

Gambar 1. Grafik konsumsi pakan domba selama penelitian

Mengetahui pengaruh pemberian jerami terfermentasi MOD-71 terhadap konsumsi bahan kering domba maka dilakukan analisa ragam. Hasil analisis ragam menunjukkan bahwa pemberian pakan menggunakan jerami terfermentasi dengan MOD-71 dengan berbagai level ( $2 \mathrm{cc}, 4 \mathrm{cc}$, dan $6 \mathrm{cc}$ ) dalam pakan domba lokal jantan memberikan pengaruh yang tidak berbeda nyata terhadap konsumsi bahan kering. Hal ini menunjukkan bahwa pemberian jerami fermentasi dengan MOD-71 tidak mempengaruhi konsumsi bahan kering domba selama penelitian. Secara statistik diketahui bahwa rataan konsumsi bahan kering pakan domba selama penelitian sebesar $497.40 \mathrm{~g} / \mathrm{ekor} / \mathrm{hari}$, hal ini menunjukkan konsumsi bahan kering rata-rata domba masih belum mencukupi sesuai dengan kebutuhan pokok bahan kering domba. Menurut Ranjhan (1981) domba yang digemukkan membutuhkan bahan kering 4.5-5 \% dari bobot hidupnya. Domba dengan bobot badan $15 \mathrm{~kg}$ akan mengkonsumsi BK sebanyak $750 \mathrm{~g}$.

Rataan konsumsi pakan domba selama penelitian menunjukkan hasil yang hampir sama, hal ini berarti domba mempunyai kemampuan dan palatabilitas yang hampir sama 
dalam mengkonsumsi bahan kering pakan. Menurut Church (1988) palatabilitas pakan dipengaruhi oleh faktor fisik dan kimiawi pakan yang akan berpengaruh terhadap fisiologis ternak dalam ransangan penglihatan, penciuman, dan rasa dalam mengkonsumsi pakan.

\section{Pertambahan Bobot Badan}

Pertumbuhan merupakan suatu indikator terjadinya deposisi nutrient dalam jaringan tubuh. Pertambahan bobot badan (PBB) Domba dalam penelitian ini diperoleh dari hasil penimbangan bobot badan akhir dikurangi dengan bobot badan awal penimbangan.

Rataan PBB domba yang diberi perlakuan berbagai level jerami fermentasi dengan MOD-71 (2 cc, 4 cc dan 6 cc) memberikan rataan PBB sebesar 20.94, 22.39 dan 20.82 g/ekor/hari dengan rata-rata konsumsi bahan kering sebesar 488.78, 491.37, dan 543.70 g/ekor/hari, hasil yang dicapai pada penelitian ini ternyata belum mencukupi kebutuhan bahan kering domba, sehingga hal ini menyebabkan rataan PBB domba dan konsumsi bahan kering domba kurang maksimal. Alasan lainnya mungkin dikarenakan domba kurang adaptif dalam mengkonsumsi jerami. Peralihan domba dalam mengkonsumsi rumput-rumputan dengan pakan jerami sebelum pra penelitian dan penelitian mengalami konsumsi rataan yang hampir sama, atau tidak terlihat perbedaan sama sekali.

Rataan pertambahan bobot badan domba sebesar $21.13 \mathrm{~g} / \mathrm{ekor} / \mathrm{hari}$. Perbedaan PBB Domba dari keempat perlakuan ini dapat diilustrasikan pada Gambar 2.

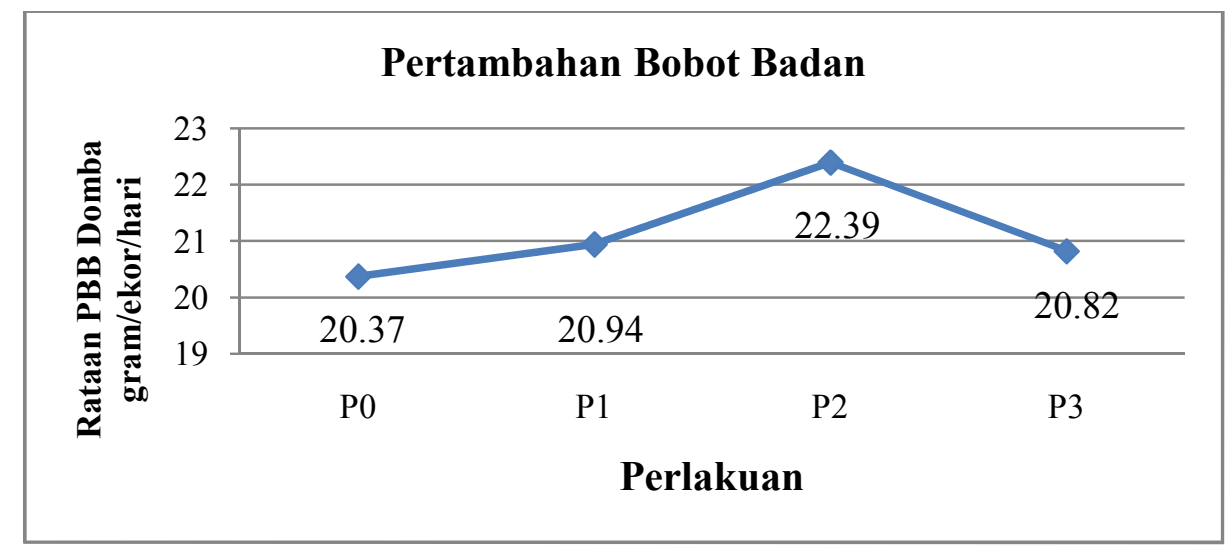

Gambar 2. Grafik rataan pertambahan bobot badan domba 
Mengetahui pengaruh pemberian jerami terfermentasi MOD-71 terhadap PBB bahan kering domba maka dilakukan analisa ragam. Hasil analisis ragam menunjukkan bahwa pemberian pakan menggunakan jerami terfermentasi dengan MOD-71 dengan berbagai level (2 cc, $4 \mathrm{cc}$, dan $6 \mathrm{cc}$ ) dalam pakan domba lokal jantan memberikan pengaruh yang tidak berbeda nyata terhadap PBB domba. PBB yang tidak nyata dapat disebabkan karena domba mengkonsumsi pakan yang jumlahnya tidak berbeda nyata. Menurut Cole (1982) menyatakan bahwa laju pertumbuhan ternak setelah disapih ditentukan oleh beberapa faktor antara lain, potensi pertumbuhan dari masing-masing ternak dan pakan yang tersedia, hal ini didukung juga oleh Soeparno dan Davies (1987) yang menyatakan bahwa jenis, kandungan gizi dan konsumsi pakan mempunyai pengaruh yang besar terhadap pertumbuhan.

Hasil penelitian diketahui bahwa rataan PBB yang diberi perlakuan jerami fermentasi MOD-71 (2cc, 4cc, dan $6 \mathrm{cc}$ ) dalam pakan selama penelitian menunjukkan hasil yang tidak berbeda jauh dengan pakan kontrol tanpa jerami fermentasi MOD-71 yaitu $21.13 \mathrm{~g} / \mathrm{ekor} / \mathrm{hari}$. Hasil ini menunjukkan perbedaan PBB yang tidak berbeda jauh juga dengan penelitian Sitanggang (2013) yang rataan PBB domba jantan lokal sebesar 20.792 g/ekor/hari. PBB domba Sei Puth jantan masih dibawah standart bila dilihat dari pernyataan Sumoprastowo (1993), yang menyatakan bahwa pada kondisi padang pengembalaan yang baik, kenaikan berat badan domba bisa mencapai antara 128.57-185.71 g/ekor/hari. Padang pengembalaan yang tidak dapat memenuhi kebutuhan domba akan mengakibatkan domba mengalami pertumbuhan yang lambat.

\section{Konversi Pakan}

Konversi pakan adalah perbandingan atau rasio antar jumlah pakan yang dikonsumsi oleh ternak dengan produk yang dihasilkan oleh ternak tersebut. Rataan konversi pakan domba selama penelitian adalah sebesar 23.58. Perbedaan konversi pakan domba dari keempat perlakuan ini dapat digambarkan sesuai dengan Gambar 3. 


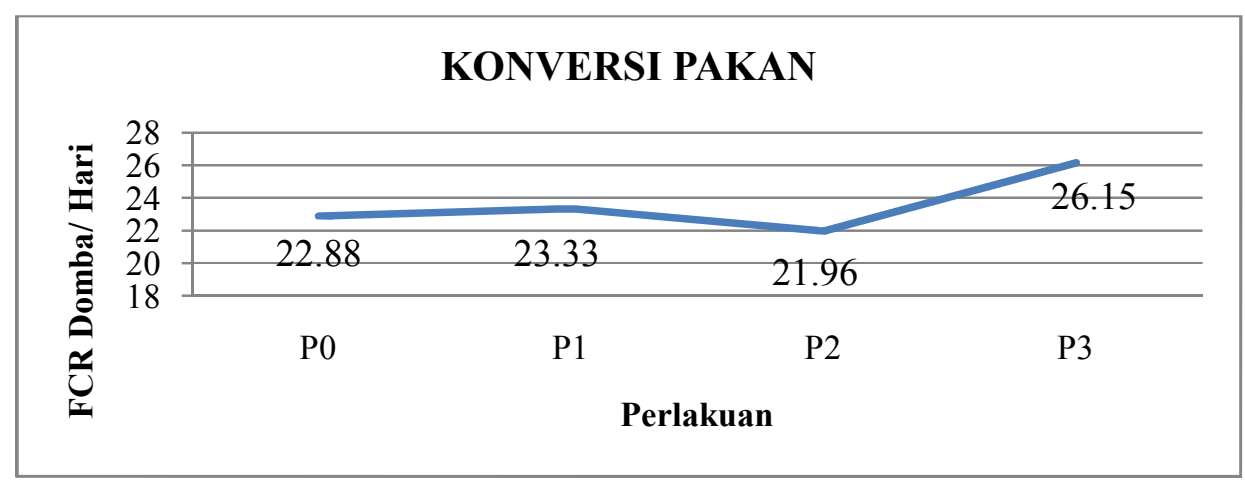

Gambar 3. Grafik konversi pakan selama penelitian

Hasil penelitian diperoleh bahwa konsumsi bahan kering ransum tertinggi terletak pada perlakuan P3 yaitu sebesar 543.70 gram/ekor/hari tetapi menghasilkan rataan PBB terendah sehingga konversi pakannya menjadi tinggi bila dibandingkan dengan semua perlakuan. Hal ini dikarenakan terjadi kehilangan bahan kering terbesar yang dikonsumsi terutama dari jerami dan hasil ikutan pertanian (konsentrat). Kaitan dengan konversi pakan yaitu proporsi bagian pakan yang hilang dan pemanfaatan lain mempengaruhi efesiensi pakan. Besaran nilai konversi pakan sangat tergantung pada kecernaan dan metabolisme nutrisi dalam tubuh ternak, dengan kata lain kecernaan sangat erat kaitannya dengan konsumsi bahan kering ransum yang berimplikasi terhadap laju pertambahan bobot badan dan efesiensi penggunaan ransum yang digunakan untuk hidup pokok dan produksi ternak. Hal ini sesuai dengan pernyataan Martawidjaja et al., (1999) bahwa konversi pakan khususnya pada ternak ruminansia dipengaruhi oleh kualitas pakan, besarnya pertambahan bobot badan, dan nilai kecernaan.

Hasil analisis ragam diketahui bahwa pemberian pakan dengan jerami fermentasi dengan MOD-71 menunjukkan tidak berbeda nyata terhadap konversi pakan domba. Konsumsi bahan kering domba yang tidak berbeda nyata sejalan dengan rataan pertambahan bobot badan dan konsumsi pakannya. Tingkat konsumsi bahan kering yang tinggi menghasilkan PBB yang tinggi pula. Kualitas dan kuantitas ransum yang baik menghasilkan nilai konversi pakan yang semakin kecil, dengan kata lain efisiensi pakan yang semakin baik dengan PBB yang semakin tinggi. Hal ini sesuai dengan pernyataan Anggorodi (1995) yang menyatakan bahwa konversi pakan adalah indikator teknis yang dapat menggambarkan tingkat efisiensi penggunaan pakan, semakin rendah angka konversi pakan berarti semakin efisien, selanjutnya dijelaskan bahwa konversi pakan khususnya pada ternak ruminansia dipengaruhi oleh kualitas pakan, besarnya PBB dan nilai kecernaan pakan. 


\section{KESIMPULAN}

Berdasarkan hasil penelitian pemanfaatan jerami padi fermentasi menggunakan MOD-71 memberikan pengaruh yang tidak berbeda nyata terhadap konsumsi pakan, pertambahan bobot badan dan konversi pakan domba jantan.

\section{DAFTAR PUSTAKA}

Anggorodi, R., 1995. Ilmu Makanan Ternak Umum. PT Gramedia, Jakarta.

Cole, V.G. 1982. Beef Cattle Production Guide, N.S.W. Up ed. Mac. Arthur Press. Parra Matta, NSW.

Church, D. C and W. G. Pond. 1988. Basic Animal Nutrition and Feeding. $3^{\text {rd }}$ Edition. John Wiley and Sons, Inc., Canada.

Martawidjaja, M., 1999. Pengaruh Taraf Pemberian Konsentrat Terhadap Keragaan Kambing Kacang Betina Sapihan. Pada: Prosiding Seminar Nasional Peternakan dan Veteriner. Balai Penelitian Ternak. Bogor.

Parakkasi, A., 1999. Ilmu Nutrisi dan Makanan Ternak Ruminansia. UI Press, Jakarta.

Ranjhan, S. K. 1981. Animal Nutrition in tropics second revised edition. Vikas publishing House PVT Ltd : , New Delhi. India.

Sitanggang, C.E. 2013. Skripsi. Pemanfaatan Jerami Padi Fermentasi dengan Probiotik Starbio terhadap Pertumbuhan Domba Jantan Lokal. USU. Medan.

Soeparno and Davies. 1987. Studies on The growth and carcass composition in the daldale weather lamb. I. The effect of dietary energy concentration and pasture species. Austr. J. Agric. Res. $38: 403-415$.

Sumoprastowo, R. M. 1993. Beternak Domba Pedaging. Bhratara. Jakarta.

Tillman, A.D., H. Hartadi, S. Reksohadiprodjo, S. Prawirokusumo, dan S. Lebdosoekojo. 1998. Ilmu Makanan Ternak Dasar. Gadjah Mada University Press, Yogyakarta. 